\title{
Social Media Impacts among Students
}

\author{
Shaheer Ahmed Ghori \\ University of Management and Technology \\ Usama Saleem \\ University of Management and Technology \\ Tahreem Shahbaz \\ University of Management and Technology
}

\begin{abstract}
As we see how social media seems to be a very popular platform among the students nowadays and it gains popularity in a very short time. Almost every student have a social media account. Nowadays everyone is busy with their mobile phones. Is social media really helping the students? Our primary purpose is to find the impact of social media growth on the students. We choose a sample of 100 students by random sampling and we use the questionnaire as a data collection instrument. We receive all the questionnaire from the students and apply descriptive statistics to analyze the data. The results have shown the different impacts of social media platforms on students some are positive but most are negative. The results also show social media addiction towards students. The reason why students mostly use social media and how much students use social media in a day.
\end{abstract}

Keywords: Students, Academics, Social Media, Internet

\section{INTRODUCTION}

Now a days, social media is widely use to get interacted with each other. Social Media is the most innovative technology in today's era. Social media breaks all the barriers of distance. It doesn't matter that the communication is between two or more people within a city or country or around the globe. In this study, social media means mobile applications that let people or organizations interact with each other or share data in a digital environment.

The mobile subscribers in Pakistan are 153.3million (Global Digital Report) and it is increasing with incredible numbers. Students and youth are the Primary producers and consumers of social media. According to Kundi (2018), 64\% is the number of people who are below the age $30 \mathrm{x}$. According to these figures, 98,752,000 mobile phone user is the youth of Pakistan.

The usage of social media is increasing day by day. Most using platforms of social media are Facebook, Twitter, Skype, Instagram, Snapchat, Text messages, Calls, Games and on the top WhatsApp. WhatsApp allow it's users to stay connected with each other and it is widely popular among people. Communication can be a text, video call or an image. WhatsApp is very helpful in sharing educational material, group discussion, sharing location, Video calling, etc.

Facebook is helping students in transforming them into the community of active learners from anonymous spectators. According to a study at Baylor University, those students who use Facebook groups as a sociology class are having better grades in their course assignments and have a stronger feeling of belonging. 
By using skype students can study in groups while sitting in their home. Skype helps them in connecting with each other through the internet. Students can also contact their teacher if they need any help on some topic.

Instagram can also use as a helpful tool for students. Students can learn photography using the Instagram app, students can share their knowledge, learn more in less time.

Snapchat can help to make a better connection between students and teachers. Students don't like email much if a teacher uses snapchat to communicate with students that will be more fun for the students to communicate with the teacher.

Text messages help students to communicate with each other through messages. Text messages are one of the best ways to can communicate with their classmates and teachers. Any type of information can be shared with the students by teachers via text messages.

Phone calls are used by everyone nowadays. It is the best way of communication among people. Students also using it for the purpose of study they can connect to their friends or teacher any time they want to while facing difficulties in some place.

WhatsApp is the most using app by students nowadays. Most of the students use the WhatsApp group in which all of their classmates are involved and share information regarding their classes. WhatsApp is also used by teachers in which teacher can make a broadcast group and they don't have to send any message to the individual student they just have to broadcast the message and every student will receive it.

Twitter can play a helpful role for those students who are involving in research projects. Students can get information and share their ideas on Twitter. According to a research Students use Twitter in writing a mini review, surveying students, tweet homework, assignments ETC. According to Kastrenakes (2019), the monthly users of twitter are approximately 321 million.

The innovation of phones from a simple phone to smartphones are the main cause of increasing social media usage. It allows users to use multiple mobile applications in just a few taps on their smartphone screen.

These social media application helping students in many ways. There is large number of researches done on the effects of social media and some researches shows different results. Most of them shows the negative effects of social media on students while in some other researches it is proved that social media is playing a very important role in learning and improving skills among students.

\section{LITERATURE REVIEW}

According to research in 2012 by Victoria, Rideout the time students spend on social media is twice as more they spend in their school each year. (Rideout, 2012).

Rideout also says a child spend 7.5hours average daily on social media and multitasking between all the social apps there use is like posting a picture on Instagram or snapchat, sending a tweet, changing or adding status on WhatsApp or gossip with their friends on any social media app. 
In a study by Abelardo Pardo, social media is a platform for innovation. This platform allows the users to share their thoughts about the something published and with the use social media students can also interact with their teachers, friends, classmates and other communities having the same interest in education. Pardo also says such interaction through social media is the essential type of humans learning (Pardo, A.2013)

Nearly $57 \%$ of the social media member's ages are between 18 to 29 years and they have personal accounts on many social media applications. (Mehmood et al, 2013). 75\% of the teens have their personal cell phones, $25 \%$ of them have social media accounts, $54 \%$ teens use for texting purpose $24 \%$ used for applications like WhatsApp and other instant message services. Most people don't realize the risk of using social media these risk including inappropriate content, privacy issues, cyberbullying, online harassment, Identity theft ETC. (O'Keeffe, G., \& Kathleen, C., 2011)

According to a study by Jocabsen et al. (2011) usage of social media platforms is creating

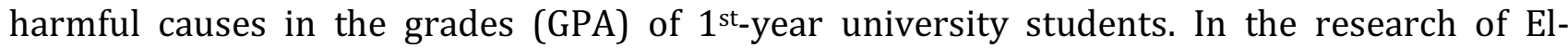
Badawy TA \& Hashem Y (2015), it's concluded that social media is not impacting the students in their academics performances

Kalia G stated in his research paper that students should be connected to each other via social media to increase their learning skills teachers should teach the students about the use of social media for their learning purposes. Social media can't only be used as an entertainment platform it can also use for education and learning purposes. (Kalia G., 2013)

In a research paper by Siddiqui S \& Singh T, they explained the positive impacts and the negative impacts of social media on students. According to their view, students can use social media to make groups of their classmates. Where they can exchange study material and other information through that platform. But these platforms also cause a distraction for the students. Most of the students don't know the terms \& policies of social media and end up misusing it. Some students make fake accounts on social media for fun propose but get addicted to social media (Siddiqui S et al., 2016)

\section{Research Method}

\section{METHODOLOGY}

The purpose of this study is to find the effects of social media on the academics of students in Pakistan. For the research, the survey method was chosen. We collect information from random students who are currently enrolled in some degree in university.

The students participate in the survey are 100 with 49 male and 51 females. They are from different age groups and different university programs. The survey also helps us to find ty social media platform among the university students from WhatsApp, Text \& calls, Facebook, Instagram, Snapchat, Twitter and Others.

\section{Research Findings}

Table 1

\begin{tabular}{|c|c|}
\hline \multicolumn{2}{|r|}{ Statistics } \\
\hline & Sample of students \\
\hline Valid Data & 100 \\
\hline Missing Data & 0 \\
\hline
\end{tabular}


The table is showing that we have collected data from 100 students and there is no missing data. All the data is valid.

Figure 1

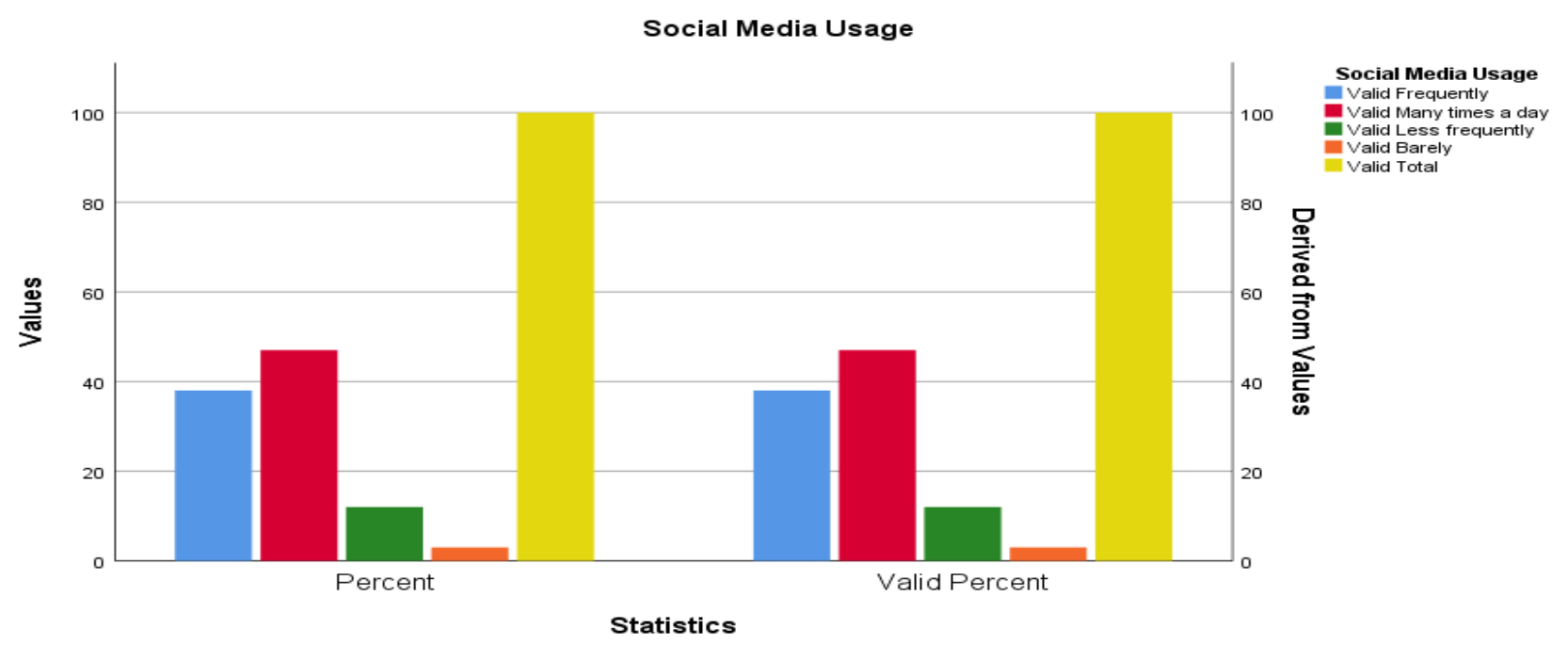

Figure 1 illustrates how frequently students use social media. Looking at the results we can clearly see that $38 \%$ of the students use social media frequently and $47 \%$ of the students use many times a day and the number of students who use less frequently or barely just $12 \%$ and $3 \%$.

Figure 2:

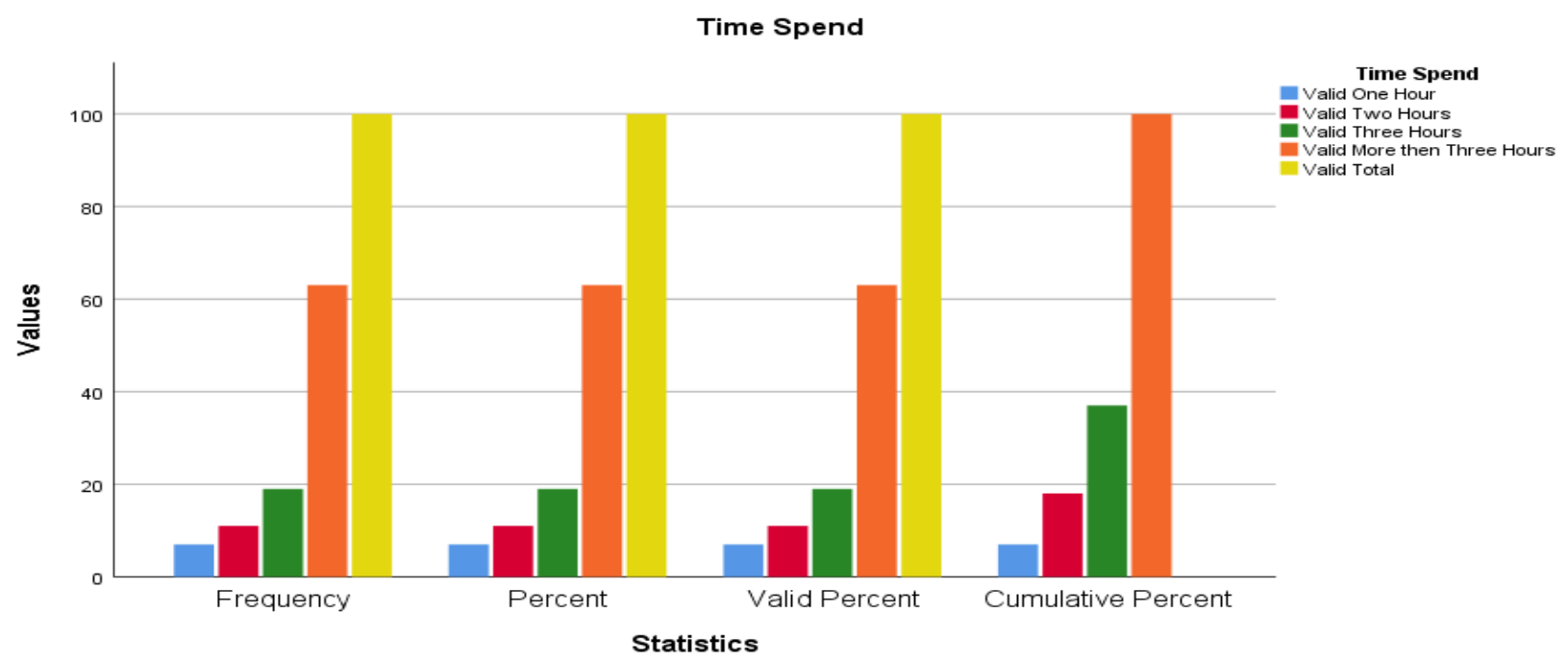

Figure 2 shows how much time students spend on their social media. The results show that there are $63 \%$ of the students who spend more than three hours a day on social media.19\% of students spend 3 hours a day, 11\% spend 2 hours a day and only $7 \%$ of the students spend 1 hour a day on social media. That's mean $63 \%$ of students spend more than $16.67 \%$ of their day on social media instead of studying. 


\section{Figure 3:}

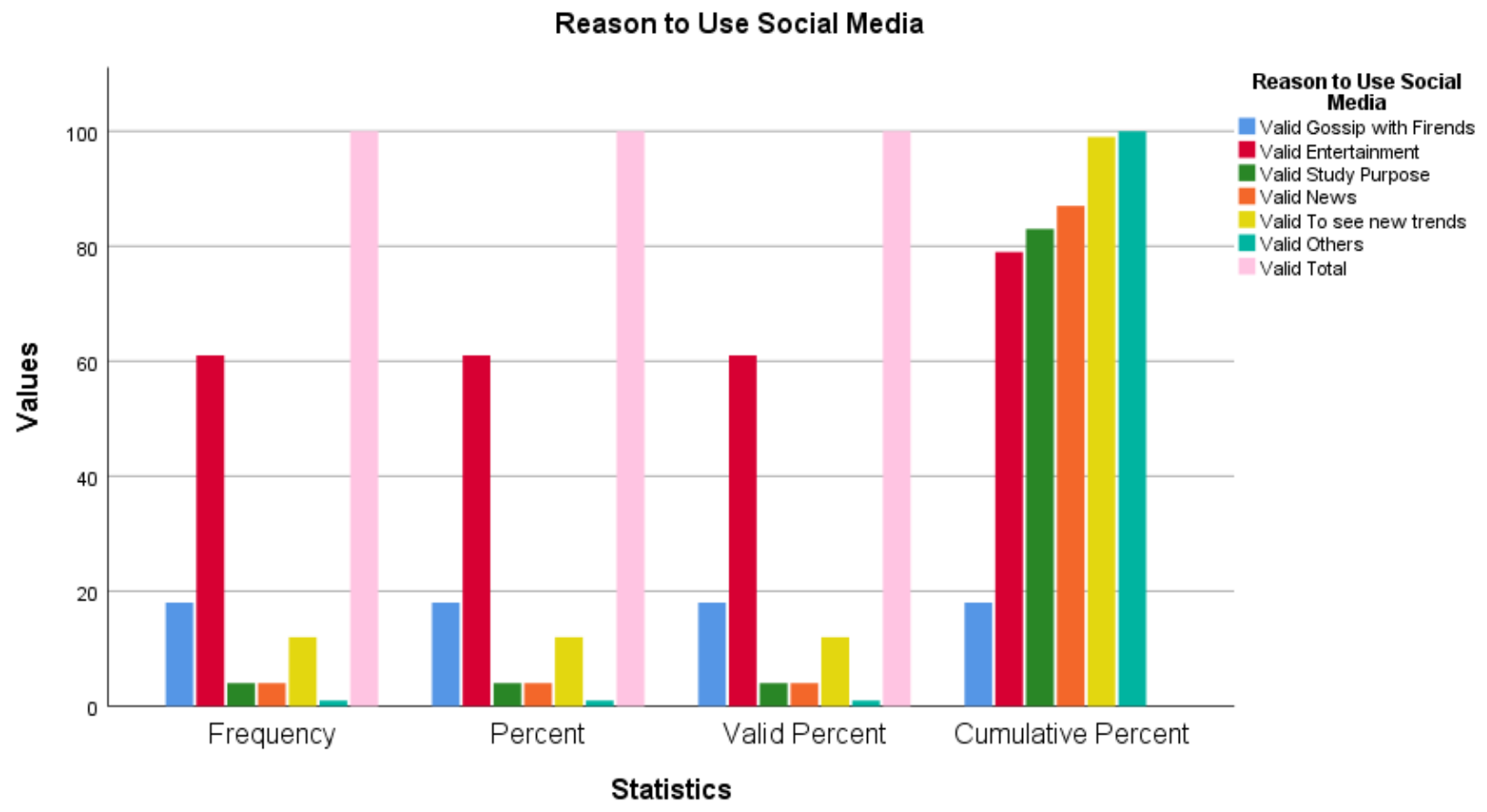

The results in figure 3 show the reason for students using social media. We can clearly see that just $4 \%$ students use social media for study purposes. $61 \%$ them use it for Entertainment, $18 \%$ of students use for gossip, $12 \%$ of them use to see new trends, $4 \%$ of them use to see news and $1 \%$ use for another purpose.

\section{Figure 4:}

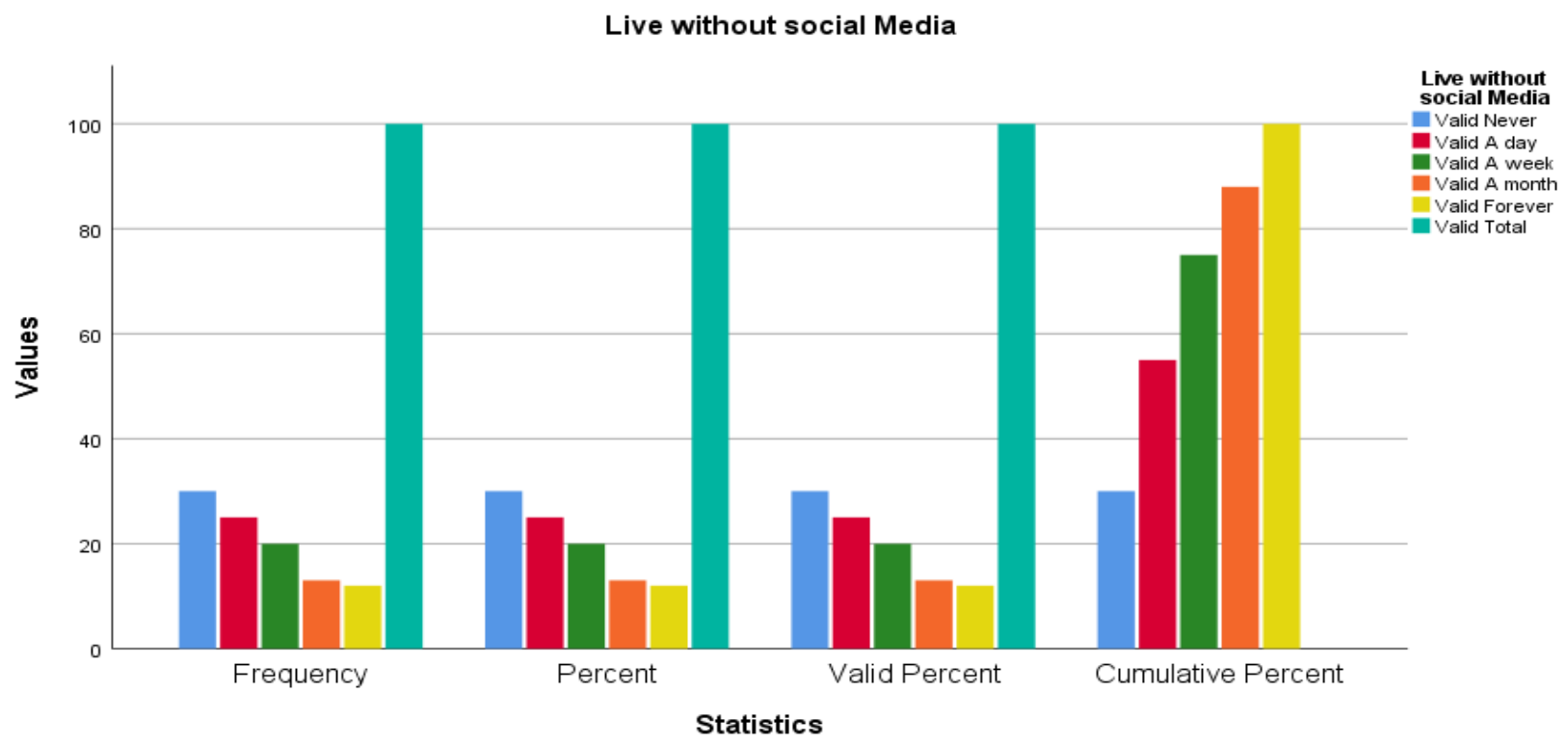

Figure 4 showing the addition of social media among students. We ask students how long they can live without using social media. $30 \%$ of the students think they can't make even a day without using social media. $25 \%$ of them think they can only quit social media for a day, $20 \%$ of students ready to quit social media for a week, $13 \%$ can quit of a month and $12 \%$ can quit forever. 


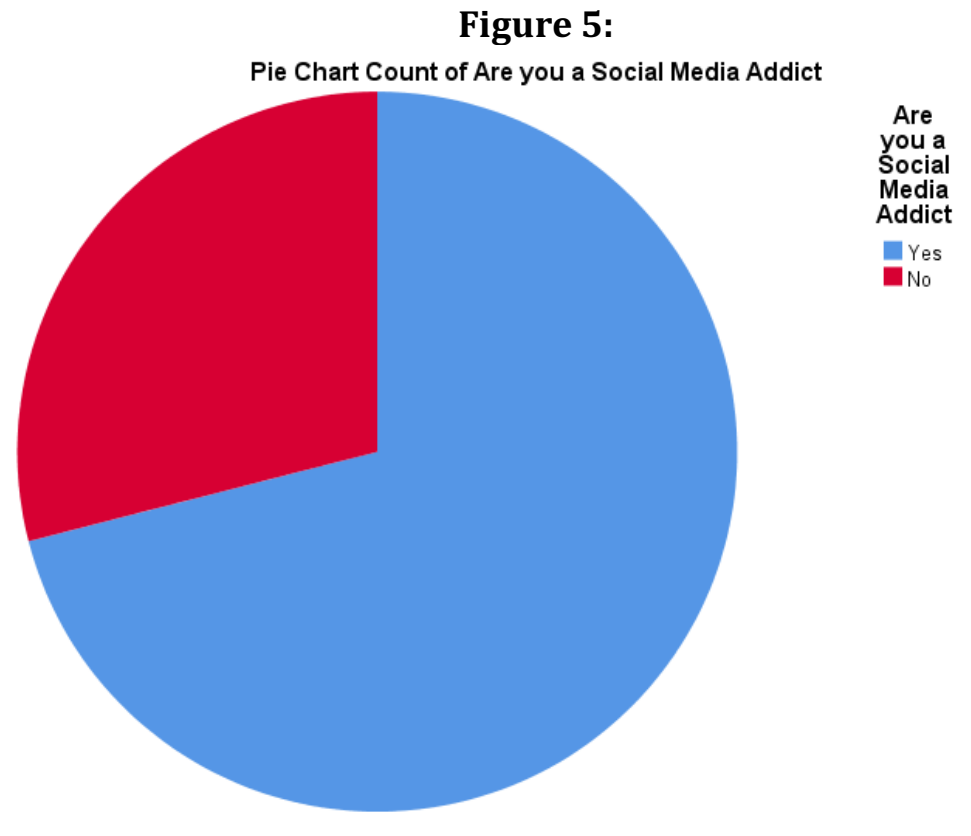

Figure 5 shows that how much students consider themselves as a social media addict. $71 \%$ of the students know that they are a social media addict. In the number of students who accept to be an addict contain $72.5 \%$ of the females and $69.4 \%$ of males.

\section{Figure 6:}

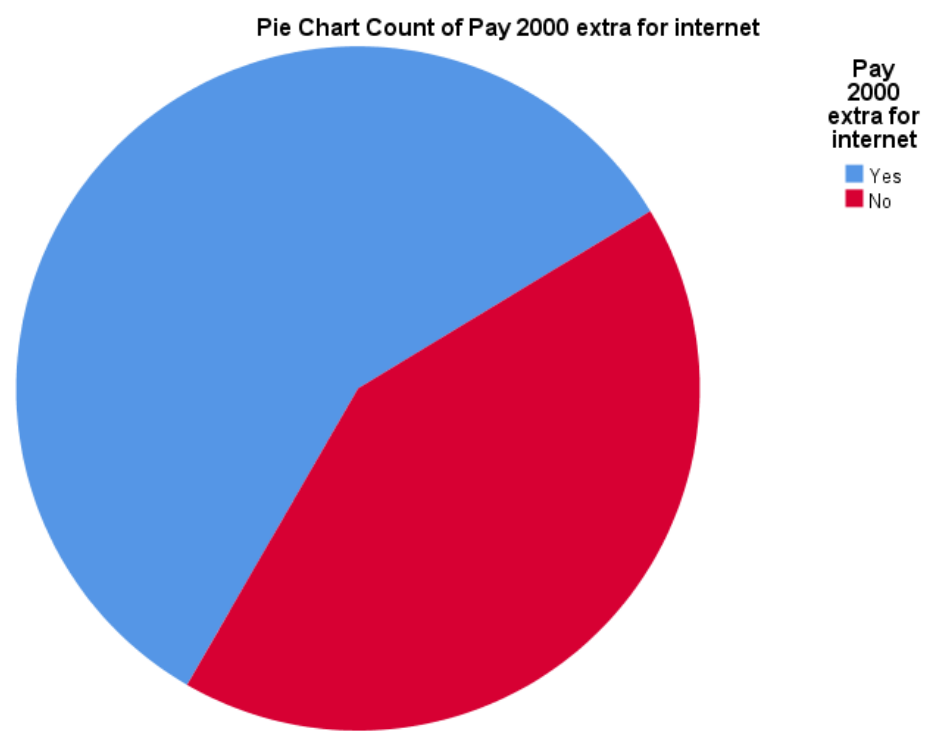

Figure 6 shows how desperately students want to use their social media. $58 \%$ of the students are ready to pay 2000 rupees extra per month if the government apply 2000 rupees fee on every person to use their social media. 
Figure 7:

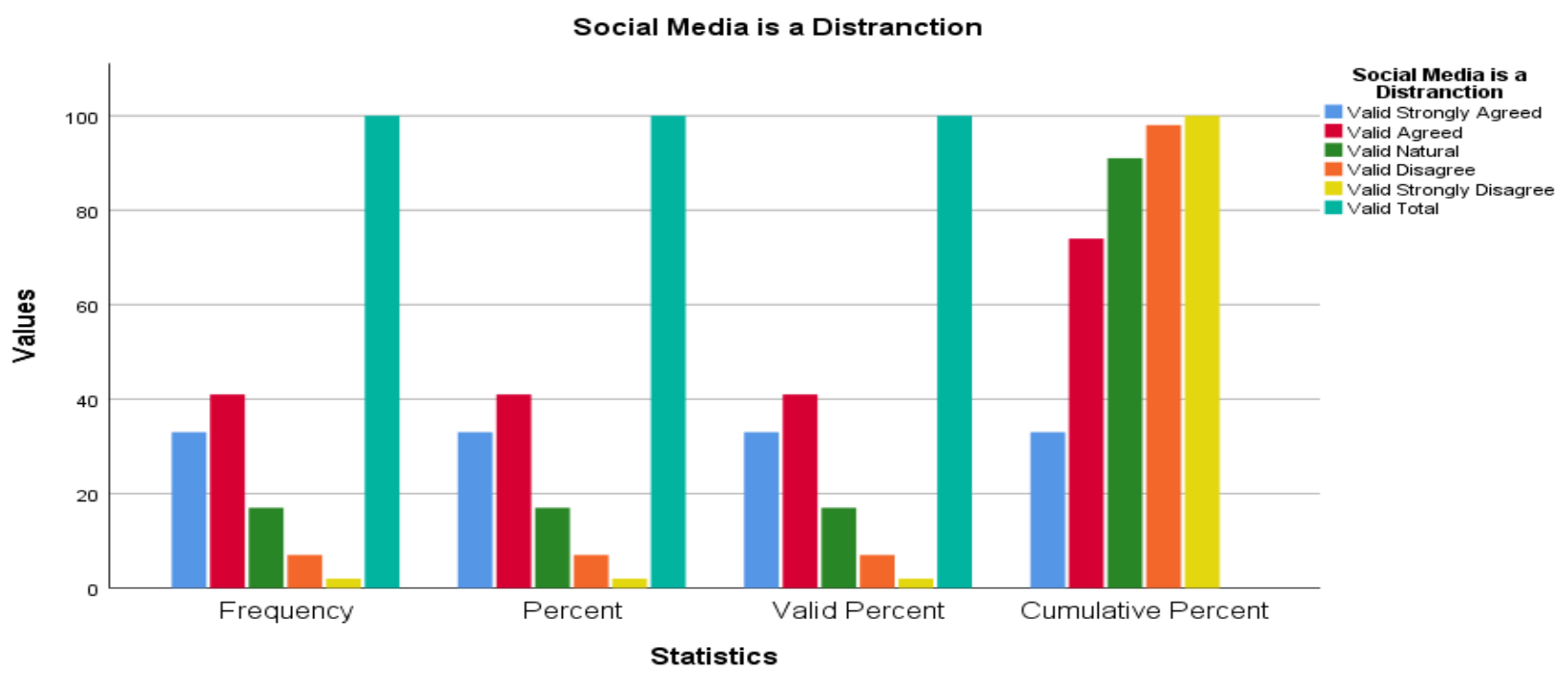

Figure 7 shows that amount of students who think social media is a distraction when they need to study. 33\% of the students are strongly agreed that social media is a distraction when they need to study. $41 \%$ of students agree that social media is a distraction. $17 \%$ of students are neutral in this question. $7 \%$ of students disagree and only $2 \%$ of the students strongly disagree that social media is a distraction.

\section{CONCLUSION}

In this phase, we conclude all the possible facts and figures that we discover after analyzing the data which we gather by our questionnaire survey. For collecting figures from our data we use SPSS software. We get results in the form of frequency tables and Bars. For data, we use some ordinal data and some nominal data. Social media is very famous among students. Every student has a social media account on multiple platforms. The figures suggested that $87 \%$ of social media users are between 18 to 22 years of age. Smart Phone is the most common medium to access social media among students. $89 \%$ of the students use their phone to access social media. The two most favorite social media applications use by students are WhatsApp and Instagram. $42 \%$ of the students select WhatsApp to be there favorite social media app and $32 \%$ of the students choose Instagram as their favorite social media application. Just $6 \%$ of students choose Facebook as their favorite social media. The most common reason to use social media we found is Entertainment more than $60 \%$ of the students use social for entertainment and just $4 \%$ use it for study purposes.

The primary purpose of this study is to find the impact of social media on students. $75 \%$ of the students found social media helpful in their study. $81 \%$ of the students think that social media help them in generating ideas. This seems to be the bright side of social media and it is. But, its other side is even darker. The impacts of social media we find by our research are way more than we expected.

\section{Impact on academics}

$74 \%$ of the students agree that social media cause distraction when they need to study and only 9\% disagree with it. This shows the students can't study well due to social media. 59.2\% of the male think they can perform well if they don't have social media and $56.9 \%$ of females think that their performance in study increase if they don't have social media. 
$62 \%$ of the students who are part of our survey accept that they use social media during their class. $63 \%$ of such students include male and $60.8 \%$ of social media user in class are females. The use of any social media platform during class cause distraction to the student. According to the figures, $62 \%$ of the students didn't listen to the lecture attentively just because they are using their mobile phone while the teacher is teaching.

\section{Social media as addiction}

Social media is not just impacting student's academics in a negative manner but also their health and mind. The results of the study we have conducted are shocking. Social media is leading students towards its addiction. $82 \%$ of students spend more than three hours a day on social media. It is like spending $12.5 \%$ of your day on social media. Social media usage is more likely to be in males than in females. $85.7 \%$ of males use social media more than three hours a day.

The most shocking fact we found in our study is $71 \%$ of the students consider themselves as a social media addict. That means everyone knows that social media is an addiction and $71 \%$ of them accept the fact that they are an addict of social media. In the number of students who accept to be an addict contain $72.5 \%$ of the females and $69.4 \%$ of males. The students in age Group of 18 to 22 year old are more likely to get addicted to social media. $72.41 \%$ of the sample in our study including male and female are from this age group.

By investigating the data we have collected from different perspectives we have found that the social media is making a negative impact on students furthermore, it is becoming a very dangerous addiction and it is increasing day by day. Our study shows that students are willing to pay 2000 rupees more per month to just get access to social media and more than $50 \%$ of the students think they can't live more than a day without social media. The students are so much into social media that we ask if there is 1000 rupees reward per day if you not open your social media account how long you will be able to make. More than half of the student's sample are able to make just 1000 because $59 \%$ of them say they can quit not more than one day even if the reward is 1000 . Social media is helping students in connecting them with their family and friends but the side effects are worse.

\section{Other effects:}

Social media is not just affecting students in academics and addiction but also cause to make a negative impact on student's mental health and behavior. $68 \%$ of the students feel peevish when they don't have access to social media. $73.5 \%$ of the males accept that they get peevish with no social media and $62.7 \%$ of female accept that. $59 \%$ of the students accept that social media is causing negative behavioral changes in them and just $12 \%$ deny it. $59.2 \%$ of male and $58.8 \%$ of the female have agreed to this.

\section{FUTURE RESEARCH}

Live every research there is a future scope in our study. First of all due to the small size of 100 the results maybe change if the sample size increases. Another study can be conducted that how come students are getting to much addicted to social media? What are the reasons? How come an application can make students addictive just by using?

\section{References}

Digital 2019: Pakistan. (2019). Retrieved from https://datareportal.com/reports/digital-2019-pakistan

Kundi,A(2018,May 03) Pakistan currently has largest percentage of young people in its history: report Retrieved from https://www.dawn.com/news/1405197 
Kastrenakes,J(2019,Feburary 07) Twitter keeps losing monthly users, so it's going to stop sharing how many Retrieved from https://www.theverge.com/2019/2/7/18213567/twitter-to-stop-sharing-mau-as-users-declineq4-2018-earnings

Rideout, V. (2012). Children, Teens, and Entertainment Media: The View From The Classroom. Commensense. Subrahmanyam, K., \& Patricia, G. (2008). Online Communication and Adolescent Relationships. The Future of Children, 18(1), 119-46. http://muse.jhu.edu/article/238863

Pardo, A. (2013). Social learning graphs: combining social network graphs and analytics to represent learning experiences. Int. J. Social Media and Interactive Learning Environments, 1(1), 43-58.

http://www.inderscience.com/offer.php?id=51652

S. MehMood, \& T. Taswir, "The effect of social networking site on the Study Performance on students in college of applies sciences, Nizwa," International Journal of Arts and Commence. Vol. 2 No. 1 pp 111-123, Oman, 2013. https://www.academia.edu/4678965/The Effects of Social Networking Sites on the Academic Performance of Students_in_College_of_Applied_Sciences_Nizwa_Oman

O'Keeffe, G., \& Kathleen, C. (2011). The Impact of Social Media on Children, Adolescents, and Families. Pediatrics, 127(4), 799-805.https://pediatrics.aappublications.org/content/127/4/800

W. C. Jacobsen, \& R. Forste, "The Wired Generation: Study and Social Outcomes of Electronic Media Utilization Among University Students.,"Cyber Psychology Behaviour \& Social Networking 18,(5) pp.6, 275-285, 2011 http://citeseerx.ist.psu.edu/viewdoc/download?doi=10.1.1.471.7633\&rep=rep1\&type=pdf

El-Badawy TA, Hashem Y (2015) The Impact of Social Media on Academic Development of School Students. International Journal of Business Administration 6: 46-52.

https://www.researchgate.net/publication/273770861 The Impact of Social Media on the Academic Develop ment of School Students/download

Kalia G (2013) A Research Paper on Social Media: An Innovative Educational Tool. Issues and Ideas in Education 1: $43-50$.

https://www.researchgate.net/publication/276926972 A Research Paper on Social media An Innovative Educ ational Tool

Siddiqui SS, Singh T (2016) Social Media its Impact with Positive and Negative Aspects. International Journal of Computer Applications Technology and Research 5: 71-75

http://www.ijcat.com/archives/volume5/issue2/ijcatr05021006.pdf 